\title{
3
}

\section{Changing concepts of socialist law in Vietnam}

\author{
John Gillespie
}

Few aspects of the Vietnamese legal system are more uncertain and controversial than the meaning of socialist law. It influences the way the Communist Party of Vietnam 'leads' the state, the way the state 'manages' society and the way officials and the public implement and obey laws. Socialist law resists definition.

'Socialist law' generates confusion because it was introduced more than forty years ago to regulate the command economy, but the term is still in use to describe contemporary mixed-market regulation. This flexible usage raises the question what is socialist about socialist law? Does the term have immutable and intrinsic meanings or has it become a convenient label for state law?

There are two main problems in assessing continuity and change in the meanings attached to 'socialist law'. First, core Marxist-Leninist notions underpinning socialist law-socialist legality, democratic centralism and collective mastery-operate at too high a level of abstraction to convey concrete meanings. Marxist-Leninist ideology informs us that law has a class element that reflects state ownership over the means of production, but says little about other social relationships such as housing, family or traffic regulations. Western 'rule of law' ideas smuggled into the recently adopted law-based state (nha пиос phap quyen) doctrine are equally uninformative. They maintain that socialist law should be equal, transparent and consistent, but rarely discuss broader normative issues. Socialist law needs middle-level propositions (an epistemological context) to acquire specific and systematic meanings.

The second analytical problem is caused by the rapidly changing and fragmenting conceptual environment shaping 'socialist law'. Socialist notions that the state owns the 'means of production' to safeguard workers' interests have dissolved into Party policies that encourage foreign investment, international 
economic integration and equitisation (co phan hoa) of state-owned companies. Ho Chi Minh's declaration that ' $[\mathrm{i}] \mathrm{f}$ the people are hungry, it is the fault of the Party and the government, if the people are cold, it is the fault of the Party and government; if the people are sick, it is the fault of the Party and the government' seems utopian compared with contemporary 'user pays' 'socialisation' policies (Thanh Duy 1997:27-8).

Our analysis needs to distinguish social change from social motion. Societies everywhere are in constant motion. Economies strengthen and weaken, social institutions rise and fall, and technology and global interaction move everyone. Yet, social motion rarely alters underlying legal meaning (Grossman 1971). We need to search for new legal meanings in the successive waves of social and legal changes that have transformed Vietnamese institutions and law.

This chapter searches for change by comparing the narratives shaping the importation of Soviet political-legal ideas forty years ago with contemporary thinking about law. Rather than attempting an authoritative definition-a project doomed by fragmented social meanings - the discussion looks for representative meanings in written records and interviews with officials within the Party and state orbit. By determining which historical contexts convey the most representative meanings, the analysis gains insight into continuity and change in 'socialist law'.

This discussion needs a framework in which to place and compare different contextual understandings about socialist law. Discourse analysis is a useful tool, since political-legal ideas are largely generated through communicative processes (Luhmann 1987; Teubner 1993; Beck 1994). Discourse is taken to mean 'all forms of spoken interaction, formal and informal, and written texts of all kinds', especially political, economic, moral, cultural and legal modes of communication (Potter and Wetherell 1987:7).

Discourse analysis does not capture every meaning of 'socialist law'. Party and state writings deterministically portray Vietnamese culture as forged in the crucible of Red River Delta culture, based on moral rule, 'led' by a morally perfected Party and possessing a low level of legal consciousness. These storylines serve to remind us that, in focusing on Party and state discourse, this investigation is limited to one (admittedly highly influential) contextual understanding of socialist law. It is important to remember that there are many legal understandings fragmented throughout the numerous discursive communities in Vietnam. The views of those from outside the Party and state orbit are discussed in another setting.

This discussion starts by mapping the main political-legal principles imported into the Democratic Republic of Vietnam from the Soviet Union. It then reflects on approaches to legal borrowing, asking why Soviet law was imported with few concessions to local practices and whether contemporary attitudes to imported laws have changed. The discussion argues that differences in the way Vietnamese policymakers borrowed ideas profoundly changed the meanings given to the 'core' Marxist-Leninist canon. It then examines contemporary narratives about law to 
ascertain whether core legal meanings are more responsive to change in some discourse modes than in others. The chapter concludes that meanings invested in socialist law are fragmenting as core socialist political-legal principles are exposed to new thinking.

\section{BUILDING A SOCIALIST LEGAL STATE}

It was not until the First Congress of the Vietnam Workers Party (Dang Lao Dong Viet $\mathrm{Nam}$ ) in September 1951 that legal cadres were instructed to 'build up socialist law' (Hoang Quoc Viet 1962:14-15). Officials in the incipient Democratic Republic of Vietnam previously characterised legality according to the French civil law concept of 'democratic legality' (phap che dan chu). The Third Party Congress in 1960 adopted the Soviet 'socialist legality' (sotsialisticheskaia zakonnost') doctrine, which translated into Vietnamese as phap che xa hoi chu nghia [a state legal ideology] (Tran Hieu 1971:108).

At first, prominent legal writers such as Dinh Gia Trinh argued that economic conditions in people's democracies like the Democratic Republic of Vietnam were insufficiently evolved to sustain Soviet-style socialist legality. ${ }^{1}$ Eventually the Soviet view, that legality in people's democracies and in socialist republics was equivalent, prevailed. By the 1970s, Vietnamese writers uniformly accepted imported socialist legal thinking as their own and unreflectively equated Soviet law with socialist law (Pham Van Bach 1970; Ngo Van Thau 1982). Assertions that Soviet law was really a public law analogue of European civil law never entered Vietnamese legal discourse.

Three doctrines constituted the 'core' socialist political-legal canon-socialist legality, democratic centralism and collective mastery.

\section{Socialist legality}

Socialist legality (phap che xa hoi chu nghia) is the main socialist legal doctrine. It was defined in Vietnamese writings during the 1960s as a tool of proletarian dictatorship (chuyen chinh vo san) to defeat enemies and to protect the revolution and collective democratic rights to organise, manage and develop a command economy (Dinh Gia Trinh 1961).

Vietnamese writers reasoned from Marxist theory that worker-controlled societies required legal systems that reflect proletarian aspirations. ${ }^{2}$ The connection between law and class was explained by the familiar assertion that law is part of the 'superstructure', which reflects the 'will of the ruling class' ( $y$ chi cua giai cap thong tri) and its control over the means of production. As the executive committee of the ruling class, the Party determined the content of law. The conflation of Party policy and law enabled the Party and state to use law as a 'management tool' (cong cu quan ly) to adjust or balance (dieu chinh) social relationships-a practice permitting the substitution of policy for law. 
That law was primarily seen as a political tool is further implied by the low priority accorded to defining legal terminology. Words such as hieu luc (validity) and tinh hop phap (legitimacy) were used interchangeably with phap che (legality). Rather than legal certainty, writers were preoccupied with generating social compliance. In an effort to make legal terms appear more familiar to villagers, scholars replaced many Sino-Vietnamese legal terms with neologisms created from everyday, but imprecise, Vietnamese terms (Dinh Gia Trinh 1965).

\section{Democratic centralism}

Democratic centralism (tap trung dan chu), as conceptualised by Lenin, was an organisational principle binding Party and state (Lavigne 1985). A facsimile of the doctrine appeared in the political report delivered by President Ho Chi Minh to the Second National Congress of the Vietnamese Workers Party (VWP) in 1951 (Ho Chi Minh 1994:127). By the time it was formally adopted in the 1959 Constitution, it had matured into a two-pronged doctrine linking popular participation in state activities with centralised Party and state power.

Party documents indicate that democratic centralism was introduced to consolidate central Party control over regional Party cadres, state officials and the general public (Le Van Luong 1960; Nguyen The Phung 1960). According to socialist strategic thinking, Party power constituted the most potent remedy to 'regionalism' (dia phuong chu nghia) and 'departmentalism'. Only a hierarchically organised, disciplined Party could deliver the social and bureaucratic unity required for command economic planning. Article 10(f) of the VWP Statute 1960 explains the meaning of 'centralism'

Individual Party members must obey the Party organisations. The minority must obey the majority. Lower organisations must obey higher organisations. Party organisations throughout the country must obey the National Delegates' Congress and Central Executive Committee (Le Van Luong 1960:33).

The second arm of democratic centralism was based on Lenin's assertion that democracy is only possible where the working class 'centralise[s] power in their hands'. ${ }^{3}$ Socialist democracy (dan chu xa chu nghia) was understood in two ways. Theorists argued that popularly elected legislatures (National Assembly and provincial legislative councils) should supervise state power on behalf of the people. Socialist democracy also encompassed Lenin's revolutionary view that bourgeois democracy transferred the people's democratic rights to elected representatives. He believed the working class had comparatively few opportunities to participate in government by influencing political decision-makers through 'lobbying' (chay lo thu tuc) and popular demonstrations. Democratic rights were better safeguarded by 'proletarian dictatorship' (chuyen chinh vo san) that empowered the 'ruling class' to supervise state organs directly through their proxies: the Communist Party and mass organisations. Democratic centralism validated Party leadership (su lanh dao cua dang) within state and society. 


\section{Collective mastery}

The ideas that eventually coalesced into the 'collective mastery' (lam chu tap the) doctrine appeared in Party publications from the 1950s onwards (Pham Van Dong 1952). Unlike socialist legality and democratic centralism, collective mastery was officially imagined through revolutionary Chinese thinking, though it drew inspiration from Lenin's assertion that true democracy is only possible where workers exercise mastery over society.

Vietnamese leaders were captivated by radical Maoist mass mobilisation theories, long after Stalinist jurists in the 1930s rejected public participation in state administration as 'the old twaddle about the mobilisation of socially active workers' (Vyshinski 1982 [1936]:81). This utopian vision enlisted law to 'fundamentally remake the conscience of the people'.

Party General Secretary Le Duan discussed collective mastery during the 1960s and 1970s, but the doctrine did not take hold until the euphoria surrounding reunification in 1975 made radical social transformation seem possible (Le Duan 1994:242-3). At the Fourth Vietnam Workers Party Congress in 1976, collective mastery was described as a system where the true and supreme masters are the social community, the organised collective of working people, with the workerpeasant alliance as the core' (Pham Van Dong 1977:K11-K12). The slogan 'the Party is the leader, the state is the manager and people are the masters' (dang lanh dao, nha nuoc quan ly, nhan dan lam chu) unified Party, state and public relationships under collective mastery (Le Duan 1979:4).

Theorists claimed that the path to collective mastery lay in eliminating conflict between the state and individuals (Le Thi 1977). This goal is evident in the Party slogan: "The important target of the revolution is to strengthen the unification between politics and the spirit of the people [tang cuong su nhat tri ve chinh tri va tinh than cua toan dan]'. In classless societies, collectivism replaced individualism, enabling people to live harmoniously without the laziness, individualism, selfishness and corruption associated with the 'old society' ( $x$ a hoi $\mathrm{cu}$ ). Collective mastery rejected civil society or individual space outside state and collective orbits as bourgeois individualism. As a corollary, the doctrine was hostile to private legal rights.

Collective values were encouraged in mass mobilisation campaigns led by the Party leadership. Early moral campaigns purged residual French cultural influences (1946-52), reformed land ownership (1953-56) and attacked 'feudalistic property ethics and Confucian morals' (Weggel 1986:415). During the 1970s and 1980s, the Party used mass organisations to mobilise popular support to 'revolutionise the whole of life' by remodelling society along state-lines (Le Phuong 1994).

Taken together, socialist legality, democratic centralism and collective mastery generated four core socialist legal principles that closely resembled the imported Soviet ideas. First, law is not above the state, but rather emanates from the state. As an extreme manifestation of legal positivism, there is no space in socialist law for customary rules or natural rights. Second, the Party and state possess prerogative 
powers to substitute policy for law. Law facilitates and orders, but never constrains state power. Third, the central 'Party leads' (su lanh dao cua dang) the state and society. Fourth, individual legal rights give way to the collective public good.

\section{IMPORTING SOCIALIST POLITICAL-LEGAL THOUGHT}

Explanations for the similarities between Soviet and Vietnamese legal thinking are found in Vietnamese approaches to legal borrowing during the 1960s and 1970s. Ignoring their own warnings against unreflective borrowing, Party leaders imported socialist law with few concessions to local conditions. Truong Chinh denounced 'gulping down raw other people's culture, parrot-fashion learning, or the mechanical introduction of a foreign culture into our own without taking into account the particularities and concrete conditions of the country and its people' (Truong Chinh 1948:251). Ho Chi Minh wrote in 1924 that 'Marxism is to be revised with respect to its historical basis, and to be consolidated by the ethnology of the East'. Later he was more direct: ' $[W]$ e are not like the Soviet Union; they have different habits and customs, history and geological conditions. We can take another road to socialism' (Ho Chi Minh 1995:338).

Their concerns rarely surfaced in the extensive Vietnamese literature concerning legal borrowing from the Soviet Union. This reluctance to localise Soviet legal reasoning is partially attributable to Marxist-Leninist hostility to the notion that culture plays a role in determining the characteristics of legal systems. Since both law and culture are located in the superstructure, their interaction is considered unimportant. The elaborate historical materialist explanations for legal development focused on linkages between European economic production and law, and said little about 'Asiatic' production (East Asian rice-growing economies) (Avineri 1969). Vietnamese theorists faced a choice between uncritically applying Marx's Eurocentric legal theory to Vietnam or comprehensively rethinking Marxist theory in the context of 'Asiatic' production. Like the Chinese, they adopted a Maoist landreform program, but applied the Soviet legal template to other social spheres.

Marx also followed a well-established European intellectual tradition that depicted Asian societies in undifferentiated ways as 'barbarians' or 'semibarbarians', portrayals that generated socialist antipathy to neo-Confucian and 'feudal' culture (Marx 1969 [1877]:6). Truong Chinh evinced this orientalist thinking when he blamed the 'Asian mode of production' for backward economic and social conditions in Vietnam. He vilified traditional cultural precepts as 'unscientific', promoting 'superstition, idealism, mysticism, bungling, carelessness, all those habits that are irrational or retrograde' (Truong Chinh 1948:25-52). Vietnamese leaders sought a 'new democracy culture' based on 'rational, progressive socialist legislation'. They considered the Soviet Union the most advanced socialist state and thought Soviet 'proletarian culture' should link the working classes in different countries. National cultural barriers based on 'Asiatic' and 'feudal' modes of production were supposed to dissolve in the face of this unifying force. 
The adaptation of imported ideology to local conditions was further constrained by ethnocentric Soviet jurists, who encouraged 'satellite' nations to 'build socialism' through imitation, rather than experimentation. In exhaustively reviewing Soviet commentaries on Vietnamese legal development, Ginsburgs (1973) blamed political policy for the reluctance to localise legal borrowings. He wrote that the

academic exploration of the distinctive attributes of socialist experimentation in the countries of the Soviet bloc became both safe and fashionable-as long, of course, as the main accent remained on the common heritage and the disparities were treated either as necessary tactical adoptions to 'objective conditions' or components in a pragmatic regionwide search for better solutions to existing socialist problems (1973:661).

Vietnamese officials working in the legal sector during the 1960s recalled that law reform sought to transplant 'proletarian culture', and Soviet advisers discouraged local adaptation as 'dangerous nationalism' (chu nghia dan toc cuc doan). ${ }^{4}$ A general reluctance to address local conditions and diverge from the Soviet legal template is revealed in a series of articles written by Soviet jurists about Vietnamese legal development (Letsoni 1963). They seldom acknowledged, much less analysed, incongruities between imported Soviet ideals and local institutional and cultural conditions. Instead, they steadfastly focused on abstract politicallegal principles such as socialist legality or procedural issues affecting civil and criminal codes (Sarogoratisk 1961). On the even rarer occasions when Vietnamese writers examined legal transplantation, discussion concentrated on narrow procedural differences between court practices (Ta Thu Khue 1963). An extensive review of the Vietnamese legal literature over this period has failed to find a single article analysing local political, economic and cultural barriers to Soviet law and organisational practices.

Finally, Marxist-Leninism promised a socialist utopia built on an infallible scientific methodology. Party leaders promoted the belief that 'Marxist doctrine is omnipotent because it is true. It is complete and harmonious' (Truong Chinh 1968:547). As an all-embracing philosophy the doctrine could only accommodate other viewpoints from a Marxist perspective. By adopting Marxist 'scientism' - a comprehensive search for the fundamental guides to life-Vietnamese leaders created a doctrinaire intellectual environment. Because the Party and state determined the class relationships that generated legal consequences, legal concepts were by definition limited to subjects approved by the state. Critical analysis of legal ideology challenged Marxist-Leninist infallibility and was politically unacceptable.

The preceding discussion suggests various factors combined to constrain local Vietnamese discourses from reshaping Soviet legal ideology

- the deterministic link between the economic base and superstructure discouraged investigation into links between law and cultural factors

- Marxism discredited East Asian economic and cultural practices

- socialism promoted a global workers' culture that de-emphasised regional differences 
- as a holistic ideology Marxist-Leninism created a closed epistemological structure that only permitted analysis from its own self-referential perspectives

- Vietnamese were reluctant to offend Soviet aid providers

- Vietnamese lawmakers reconciled law and society through pragmatic experimentation (learning by doing) rather than theorising.

\section{ADAPTING SOCIALIST LAW: SEARCHING FOR VIETNAMESE LEGAL DISCOURSE}

Unlike socialist legality, Soviet organisational principles (democratic centralism and collective mastery) were consciously applied to and mixed with local political and moral ideas. Following independence, Party leaders soon discovered that imported egalitarian Soviet ideals could not easily displace neo-Confucian values and hierarchical practices (Hoang Quoc Viet 1964). While authorities struggled to apply socialist legality in everyday life, they pragmatically mixed Soviet organisational principles with pre-modern moral principles to get 'in touch with the people' (duong loi quan chung) (Thanh Duy 1997:27-8). Since people responded to tinh cam (sentiment) more readily than to abstract socialist legality, revolutionary morality was used to mobilise public support (collective mastery).

Party theorists developed revolutionary morality by mythologising continuities between pre-modern morals and Marxist-Leninism (Nguyen Khac Vien 1974). Revolutionary morality promoted shared communitarian values-the idea that people are 'a totality of their social relationships', 'collective discipline' and the 'fulfilment of social obligations'. Confucianism and Marxist-Leninism were not entirely compatible because Marxist materialism discredited Confucian spirituality social hierarchies.

More generally, revolutionary morality not only shared a similar moral outlook, but also a comparable administrative style with pre-modern governance. Ho Chi Minh frequently stressed the importance of moral leadership by the Party (Nguyen Khac Vien 1974; Quang Can 2001). He opined that '[i]f one does not have morality, one can hardly lead the people, however talented one can be' (Ho Chi Minh 1995:338). Party leaders were expected to 'display higher knowledge than ordinary people... act with lucidity and clear-sightedness and...look farther and wider than others' (Song Thanh 1995:6). Once Party leaders had attained a higher revolutionary morality—like mandarin 'first knowers' - they were obliged to instruct and guide those with less 'class sentiment or awareness' (tinh cam giai cap).

Like Confucian rule, revolutionary morality personalised state-society relationships. Theorists aimed to 'strengthen the unification between politics and the spirit of the whole people' (tang cuong su nhat tri ve chinh tri va tinh than cua toan va phap) by infusing personal relationships between cadres and the people with class sentiment or awareness. ${ }^{5}$ If the masses were awakened (giac ngo) to class sentiment or awareness, they would respect the Party as the highest 'revolutionary 
moral' (dao duc cah many) authority. Party cadres in practice complained that the people followed orders from those they liked and ignored those from whom they disliked. Many officials were not originally from the working class and required constant reminding to remain close to the people.

Pre-modern and socialist organisational principles converged in three areas: raising public interests over individual interests, promoting the state to lead society and treating law as a tool to maintain social order.

The preceding discussion implies that socialist legality and socialist organisational principles (for example, democratic centralism and collective mastery) engaged different Vietnamese narratives. Soviet-trained Vietnamese lawyers imported socialist legality into a reified Soviet-influenced legal environment that rarely engaged the world outside élite legal institutions. Despite potent political and epistemological constraints, Soviet legal reasoning was not entirely isolated from local discourse. Through cultural osmosis it slowly acquired meanings from residual imperial Vietnamese and French legal epistemologies. Take, for example, the SinoVietnamese term phap che, which was used to translate the Soviet word for 'legality' (Dinh Gia Trinh 1964a). While phap che retained its Soviet meaning in scholarly discourse, in political discourse it reverted to its pre-modern legal meaning-to 'ensure legal compliance' through mass legal or moral education campaigns.

Vietnamese legal personnel extended the process of acculturation by pragmatically adapting Soviet laws to suit Vietnamese legal institutions (Nicholson 2001). But they were content with highly contextualised, technical adjustments and did not meditatively theorise a distinctly Vietnamese socialist law.

Various factors discouraged lawmakers from conceptually reconfiguring Soviet legal theory to suit local ideas and practices. Marxist-Leninist theory disassociated law from cultural relationships. It also assumed that a global workers' culture would flatten out regional differences separating socialist countries. Most policymakers presupposed the infallibility of Soviet thinking and sought ways to make society resemble law, rather than making laws resemble society. They placed socialist law in a closed epistemological system with few points of communication with local moral and cultural thinking.

In contrast with socialist legality, democratic centralism and collective mastery concepts were interwoven with local political and moral arguments promoting Party 'leadership' (Nguyen Khanh Toan 1964). They stressed hierarchies and communitarian sentiments that were analogous to, and easily blended with, Ho Chi Minh's revolutionary virtue-rule. Moreover, they primarily addressed Party and state cadres-the group most influenced by the imported socialist 'workers' culture'. In the end, Soviet organisational principles established the Party and state architecture and the revolutionary virtue-rule regulated governance practices.

Incompatibilities between imported legality and political and moral virtue-rule did not especially matter in the command economy, where the state primarily used discretionary powers to order society. Legality began to assume more importance when the Sixth Party Congress in 1986 formally agreed that 'management of the 
country should be performed through laws rather than moral concepts'. By this time, market forces were already undermining the administrative apparatus used to dispense virtue-rule. After decades without significant change, external conditions forced a discourse between socialist legality and local deliberations.

\section{CONTEMPORARY LEGAL BORROWING}

This section examines contemporary political, economic, moral, cultural and legal discourses for new meanings about socialist law. Following the doi moi reforms in 1986, lawmakers began searching beyond the socialist world for legal inspiration. It is argued that the conceptual debates used to justify importing capitalist legal norms into commercial laws have significantly reconfigured some core beliefs underpinning socialist law. ${ }^{6}$

\section{Political discourse}

The Seventh Party Congress in 1991 changed the socialist political-legal canon by adding law-based state (nha nuoc phap quyen) concepts to socialist legality, democratic centralism and collective mastery (Do Muoi 1992). The law-based state promoted a procedural 'rule of law' based on stable, authoritative and compulsory law; equality before the law; and the use of law to constrain and supervise enforcement and administration. It also proposed a separation of Party and state functions where the Party was supposed to formulate socioeconomic objectives, leaving the state apparatus to enact and implement the Party line.

Far from producing legal certainty, the law-based state failed to clarify whether the Party retained prerogative powers to substitute policy for law. The Constitution in 1992 appeared to place the Party under the rule of law, but it also reaffirmed the constitutionality of socialist legality, democratic centralism and collective mastery, doctrines that promoted Party paramountcy over law.

Dao Tri Uc (1999:18), a prominent legal scholar, recently confirmed the MarxistLeninist basis of law, stating that

[1]egality (phap che) in general is the way to organise society, to put social life into the order that fits with the will of the ruling class. If laws are the legalised will of the ruling class, arising from the contemporary needs and social conditions of the ruling class, legality must be understood as the process to put that will into real life, making it reality. Thus, for us, legality has the same meaning as the need to institutionalise the requirement that state administration and social administration benefit the working people.

Recalling Marxist 'scientism', this narrative first asserts that Marxist-Leninism and the thoughts of Ho Chi Minh are infallible and eternal truths. It then applies this a priori 'truth' to show that law reflects the 'will of the ruling class' ( $y$ chi cua giai cap thong tri). As the executive committee of the 'ruling class', the Party decides which laws 'benefit the working people' (Nguyen Van Thai 1996:3,7).

This political image of socialist law has been so successfully inculcated through Party policy, university and professional training courses and workplace practices 
that many Vietnamese legal officials treat socialist law as indigenous thinking (Le Honh Hanh 1998; Le Minh Tam 1998). Recycling decades-old notions that Vietnam belongs to an international socialist family (gia dinh xa hoi chu nghia), many officials believe that socialist law is compatible with Vietnamese precepts because it originated from a similar 'political system' (he thong chinh tri). In the socialist family, the Soviet Union was considered the 'elder brother' and 'family members' followed what they were told.

Some theorists have reconfigured class theory to make it more relevant to lawmakers, who are now required to borrow laws from non-socialist sources. Using class-based law as his theoretical compass, Dao Tri Uc (1995) developed a methodology to guide lawmakers borrowing norms from the Lê and Nguyen dynasty codes. He reasoned that Imperial Laws were composed of two basic elementssocial norms that regulate common interests and rules designed to advance imperial families. 'One should not jump to the conclusion', he wrote, 'that the first aspect [norms regulating common interests] is progressive and should be inherited, while the second aspect [laws promoting imperial families] is counter-progressive and therefore should not be inherited' (Dao Tri Uc 1995:39). On the contrary, in his estimation, feudal laws were 'progressive' and worth borrowing, provided they did not conflict with common interests or the national interests. Departing from orthodox class-based thinking, he urged contemporary lawmakers to select laws from premodern sources that reflected the interests of the working class or that promoted national goals.

For Dao Tri Uc, law in the superstructure should reflect both national and worker interests. His reformulation of the link between the will of the working class and law gave lawmakers a theoretical licence to borrow laws from capitalist countries. He ultimately concluded that the purpose of law was to implement the Party linea formulation that is consistent with the principles of orthodox democratic centralism and collective mastery (now renamed people's mastery or lam chu nhan dan). It remains to be seen whether theorists working in other disciplines are prepared to change core Marxist-Leninist principles fundamentally and constrain Party political power with law.

\section{Economic discourse}

Market reforms have influenced legal discourse more than any other single factor. Economic arguments have challenged legal thinking about Marx's causal link between the 'economic base and superstructure', 'state economic management' (quan ly nha nuoc kinh te) and international legal harmonisation.

Party resolutions recognising private ownership have emboldened some economic writers to adapt the Marxist canon imaginatively to market conditions (Vu Anh Tuan 1998; Vo Khanh Vinh 1997). Some writers reaffirmed old orthodoxies that the 'economic system of a society determines the nature and form of its legal system', but used this argument to assert that changes in the 'base' or 'mode of production' induced by private ownership should be reflected by corresponding 
legal changes in the 'superstructure'. By this, they mean market laws in the superstructure should reflect mixed-market economic relationships. This new application of conventional Marxist thinking removes conceptual obstacles to importing rights-based market laws into the superstructure.

Strongly influenced by Chinese Marxist theorists (Shih 1996), other Vietnamese writers insist that 'laws have their relative independence and influence on the economic system' (Vu Anh Tuan 1998:26-7; Le Minh Quan 1997:28-31). In other words, the economic base and superstructure co-exist with 'relative autonomy'. This radical revision of Marxist orthodoxy not only removes conceptual obstacles to borrowing laws from non-socialist economies, it also abandons the core socialist idea that law reflects class interests.

State economic management. Especially after the Fourth Vietnam Workers Party Congress in 1976, Soviet state economic planning became the primary regulatory instrument (Cong Tac Ke Hoach 1976). State planners needed administrative mechanisms to implement plans. Devised in the Soviet Union to link planning and economic production, 'state economic management' (quan ly nha nuoc kinh te) unified political and economic leadership in the state (Nguyen Nien 1976:34-6). 'State economic management' possessed a 'party nature' (tinh dang cong san), which gave Party and state authorities broad 'prerogative' powers to fine-tune economic production (Hoang Quoc Viet 1973:8-12; Le Thanh Nghi 1975).

Calls by legal writers in the 1970s to legalise and systematise command planning with an economic code were rejected. Party leaders argued that prerogative powers were needed to 'organically link' the Party's economic line with economic regulation. 'State economic management' gave the Party and state extra-legal prerogative powers to micromanage the economy.

Following doi moi reforms, regulatory tensions between imported market liberalism and 'state economic management' have increasingly surfaced in legal discourse (Doan Trong Truyen 1997). Views range from the neoliberal claim that states should only intervene to prevent market failures to orthodox state managerial models. ${ }^{7}$ Neoliberal theorists argue for a facilitative legislative framework administered by reactive state institutions such as courts. This regulatory formula limits state intervention to correcting market pathologies and deregulating 'asking giving' (co che xin cho) discretionary business licences. Neoliberal economic ideas are clearly evident in foreign donor-funded legal reforms, such as in the Comprehensive Legal Needs Assessment (LNA) Report, ${ }^{8}$ which provides that

- citizens may do everything not expressly prohibited by law

- the 'state must not do anything, except that which is expressly permitted by law'

- citizens should have increased powers to 'know, discuss and check' state power.

There is little discernable support for neoliberal economic ideas in the legal literature. A small number of Vietnamese legal academics are convinced 'state economic management' compromises liberal market rights, such as freedom to 
conduct authorised business activities (Pham Duy Nghia 2002; Pham Duy Nghia 2000). However, they remain sceptical about whether sweeping economic deregulation designed to remove bureaucratic discretion is an appropriate economic policy for a poor country experiencing uneven wealth creation. Instead, they support the Keynesian view that states should proactively redistribute wealth according to need.

Other commentators favour a Japanese-style proactive regulatory model. ${ }^{9}$ They agree with neoliberal theorists that transparent legal systems encourage market stability and predictability, but believe that economic growth requires 'Rhine capitalism', where proactive states regulate economic producers (Vu Tuan Anh 1994:253-4). They believe there is an ongoing role for 'state economic management' in controlling large state-owned enterprises and micro-managing the private sector. In their estimation, legal rules should constrain the exercise of prerogative 'state management' powers.

At the other end of the regulatory spectrum, most commentators still support orthodox 'state economic management' that gives regulators extra-legal prerogative powers to manage the economy (Vu Ngoc Nhung 1999). They stress the compatibility between socialism and mixed-market economies-'commodity production is not the opposite of socialism'. They also consider 'the marriage of the private sector with a "socialist orientation" is one of convenience, not true love' and the 'market economy following a socialist orientation' (kinh te thi truong theo dinh huong xa hoi chu nghia) is a necessary transitional stage on the road to socialism (Luu Ha Vi 1997:1-4). 'State economic management' is thought necessary to ensure the economy follows the 'socialist' way.

Party enthusiasm for 'state economic management' likewise seems undiminished by market reforms. Although the Resolution of the Fifth Plenum of the Party Central Committee in 2002 endorsed private sector development, it also reaffirmed that the 'socialist-oriented market economy is placed under state management'.

Perhaps because it directly concerns politically sensitive prerogative powers, published writings rarely critically evaluate the relevance of 'state economic management' in a mixed-market economy. This reticence is also found in unpublished postgraduate dissertations that discuss the application of 'state economic management' to new commercial sectors such as the stock market or foreign banking. Rather than questioning the relevance of a command economy regulatory system, researchers have searched for ways to strengthen state control. Support for 'state economic management' is also found in some academic writings. Mai Huu Thuc (2001:23-4) obliquely argues that 'state economic management' is required to realise Party-mandated socioeconomic objectives. Hoang The Lien, the author of the 'Legal Needs Assessment Legal Institutions Report', was more explicit in recommending legal institutions reform to 'improve leadership by party organisations over economic and financial management' (Ministry of Justice 2002:40). International economic integration. Arguments supporting international economic integration have profoundly influenced legal thinking. Contrasting with the cryptic and coded references to 'state economic management', international economic 
integration is vigorously debated. By the mid 1980s, Party leaders concluded that central planning, trade with Eastern bloc countries and import-replacement strategies could not replicate the economic growth experienced by Vietnam's neighbours (Fforde 1999:44-63). In 1986, the Party adopted an 'open door' (mo cua), adopting policies of cautiously opening the economy to foreign trade and investment from capitalist countries. Most Vietnamese commentators attribute this reorientation more to economic necessity than to an ideological shift towards free trade. Nevertheless, officials realised

the biggest factor that may influence the direction of Vietnam's future trade policy is the
integration of this country into regional and international economic organisations. The
process of joining the WTO compels Vietnam to adjust its whole trade system in accordance
with the rules and disciplines of this organisation (Tran Thu Hang 1999:121).

Entry into a bilateral trade agreement (BTA) with the United States in 2001 in some ways overshadowed WTO accession, which is currently scheduled for 2006. The BTA contained most WTO entry conditions and some additional provisions requiring Vietnam to change institutional structures to improve administrative review over 'state economic management' and widen market access for foreign legal practitioners. ${ }^{10}$

Opinions concerning international economic integration are polarised. Most government sources uncritically promote integration (Nguyen Minh Tu 1999). Numerous studies have attempted to demonstrate that integration has improved domestic economic growth and reduced poverty (Giang Chau 2003; Minh Khuong 1999). The 2001-10 Socio-Economic Development Strategy, issued by the Ninth Party Congress in 2001, endorsed this position.

Not everyone in the Party supports economic integration. Nguyen Tan Dung, a Politburo member, cautions that integration and globalisation will erode national sovereignty

Economic independence and sovereignty means first of all not being governed by or dependent on the outside for economic development lines and policies, on the economic and/or political conditions they wish to impose on us for assistance, bilateral or multilateral cooperation, the conditions which will cause harm to our national sovereignty and national basic interests (Nguyen Tan Dung 2002:3).

Underlying his concern is the fear that international integration may compromise the capacity for state-owned enterprises to 'constitute an important material force and macro instrument for the state to orient and regulate the economy'. Put more generally, the national interest (that is, food, energy, environment and socioeconomic infrastructure) and economic growth supported by local capital and technology should be protected from foreign economic influence. Such views are heavily coloured by nationalism and deeply ingrained notions of 'self-sufficiency' (phat huy noi luc; literally, to promote internal strengths). Those advocating self-reliance believe the erosion of national sovereignty outweighs the putative benefits of international trade and investment (Pham Van Chuc 2002). 
For different reasons, other economists have questioned the government's assertion that international economic integration is an unqualified good (Tran Viet Phuong 1999). Their research shows that international trade and investment can increase social inequality, a topic that is conspicuously absent from most government literature. Rather than passively accepting economic globalisation, they argue that careful state intervention can anticipate and reduce many harmful side-effects. Their writings are free of the visceral fears about foreign dependency animating political critiques.

Unsurprisingly, government legal writings unreservedly embrace international economic integration. The Final Report of the Legal Needs Assessment is unequivocal in its support

The concept of proactive international economic integration must be instilled in the development and completion of the legal system of Vietnam in all fields, from lawmaking and implementation, to legal education and dissemination. Vietnam's legal system should not only reflect the specific features of this country, but also must meet international standards in order to be able to help Vietnam perform her international commitments based on the principles of national independence, self-determination and socialist orientation (Ministry of Justice 2002:25).

International integration was put beyond doubt by the LNA action plan, which gave priority to legislative reforms required for BTA and WTO membership.

Critiques by commentators following the government's integrationist line generally considered narrow technical issues. Some have reviewed domestic statutory changes required to satisfy Most Favoured Nation, National Treatment and international intellectual property conditions imposed by the WTO (Tran Van Nam 2002; Nguyen Thanh Tam 2001). Others have described the reforms to administrative review required to meet treaty obligations (Hoang Phuoc Hiep 2001). Their work is distinguished by a reluctance to link legal harmonisation with broad economic arguments that legal harmonisation will create economic winners and losers. Only a few academic legal writers have queried government policy by suggesting that legal harmonisation should aim to minimise domestic economic dislocation (Pham Duy Nghia 2001).

To summarise, shifts in Marxist economic thinking have made legal borrowing from capitalist countries theoretically respectable, but at the same time the role of 'state economic management' in the mixed-market economy is unresolved. Legal discourse reflects this uncertainty. It oscillates between the neoliberal legal language that permeates foreign donor discourse and the ambiguous messages in Party and government writings about 'Party leadership' over the economy.

With some notable exceptions (discussed below), legal discourse rarely considers the institutional and epistemological incompatibilities generated by superimposing a rights-based legislative framework over a Soviet-inspired legal system. Most contemporary writers focus on narrow legal technicalities without engaging in broader discursive narratives. In dismissing indigenous business culture as suboptimal or non-existent, writers assume that international legal harmonisation is 
simply a technical adjustment between legal systems. Further, unreflective borrowing is politically prudent, because critical research may implicitly fault Party policy by questioning economic integration.

Uncritical law reform did not especially matter in the command economy, because officials could reconcile gaps between law and reality with 'state economic management' discretionary powers. This strategy is becoming less tenable in contemporary Vietnam, because foreign investors are prepared to test legal rights introduced in borrowed capitalist laws. Legal contests will bring into focus competition between extra-legal prerogative powers and legal rights, and the political, moral and legal rationales underpinning these regulatory approaches.

\section{Morality}

There is a long-standing tension between moral and legal discourse in Vietnam. Moral discourse was historically privileged over legal arguments (Ta Van Tai 1982). As we have seen, virtue-rule more than legality regulated pre-doi moi Vietnam. Legality was officially encouraged by the Sixth Party Congress in 1986, but rule through law was not formally accepted until the Seventh Party Congress endorsed the 'state-based law' (nha nuoc phap quyen) doctrine in 1991 (Do Moi 1992:30-8). By this time, most legal writers recognised that the separation of law and morality is a prerequisite of rights-based legal systems (Nguyen Nhu Phat 1997).

Although it has significantly reconfigured socialist legality, law-based state discourse has had little impact on the Soviet organisational principles (democratic centralism and collective mastery) that legitimise Party moral 'leadership' (su lanh dao cua dang). For every official pronouncement that law governs state-society relations, other narratives strongly imply that moral rule is still a vital source of legitimacy and normative standards for Party leadership. The Party and state insist that 'the CPV is the political force leading the whole system.... and reforms of the political system should absolutely not touch the decisive point that the CPV has the sole leading role' (Hoc Vien Hanh Chinh Quoc Gia 1991:11-9).

The contemporary importance of moral rule is inferred from the unrelenting efforts to portray the Party as infallible-a moral exemplar. Reprising Ho Chi Minh's assertion that the 'Party is morality', Tran Xuan Truong (2002) recently declared 'our Party is civilisation'. Nguyen Phu Trong (1999:7), a member of the Politburo, grandiloquently described the Party as 'the intellect, the honour, the conscience of our time; the Party is the embodiment of the wisdom, quality, the quintessence of the nation'.

Moral rule is further implied by the Party's preoccupation with moral perfection. The Central Committee's Political Report to the Ninth Party Congress in 2001 proposed the following measures to strengthen Party leadership: forge revolutionary ethics, combat individualism, promote exemplary behaviour, and concentrate on self-improvement (Communist Party of Vietnam 2001). Public administration reforms aiming for meritorious recruitment and promotion were also recommended, but as 
an adjunct to the moral perfection underpinning 'Party leadership'. Government reports are also full of accounts attributing the gap between legislative objectives and social behaviour to poor implementation by officials who lack ideological knowledge and deviate from Party morality (Ngo Cuong 1997). They resemble in substance and tone the moral justifications for legal violations in legal writings during the 1960s.

It is important to recognise the potential for transformative change. Evidence suggests that market forces and international treaty obligations are compelling the Party to replace moral regulation with due process and legal transparency. As foreign and domestic investors increasingly challenge the discretionary outcomes produced by moral rule, it is plausible that the Party and state will search for alternative sources of institutional order-legal sources of order. Moral solutions are difficult to sustain in a socially pluralistic mixed-market economy.

Preliminary research suggests the shift from moral to legal regulation is already well advanced in the economic arena (Nguyen Thi Oanh 1998:3). Once moral rule declines in importance as a regulatory instrument, it is possible that the Party will open moral discourse to public debate. In the meantime, legal writers rarely mention moral rule, much less the appropriateness of political morality. Their silence contrasts with the vigorous exchanges concerning cultural borrowing.

\section{Culture}

Vietnamese writers are fascinated with the role culture plays in social and economic development. ${ }^{11}$ Many themes run through this discourse, but two concepts support the proposition that attitudes to cultural identity shape the way people approach legal borrowing. The first account infers from traditional village practices an authentic national culture (van hoa dan toc) surrounded by layers of received external influences (Dao Minh Quang 1993). Some writers in this tradition deride mandarin literati for 'worshipping' Chinese culture and consigning indigenous Vietnamese state and legal apparatus to a quagmire of neo-Confucian dogmatism and conservatism (Vu Khieu 1999; Dao Tri Uc and Le Minh Thong 1999). Like articles of faith, certain Vietnamese institutions like Red River Delta villages are placed within the traditional core, while other practices, particularly those derived from colonial and foreign sources, are relegated to the social margins. Such views are especially evident in political tracts designed by Party leaders to highlight a culture in opposition to foreign influences (Le Kha Phieu 1998).

Contesting this nationalistic portrayal of the Vietnamese as heroic resisters against foreign domination, a second counter-narrative portrays Vietnamese culture in dialogue with foreign influences. Some commentators maintain that during the initial stages of anti-colonial resistance most Vietnamese intellectuals treated French culture with disdain (Dao Tri Uc and Le Minh Thong 1999). Later, when traditional values proved unable to combat colonial domination, prominent Vietnamese began to selectively borrow imported precepts and practices. Nationalist leaders such as 
Phan Boi Chua and Phan Chau Trinh were influenced by French legal ideas such as civil rights and constitutionalism. Later still, lessons learnt by Ho Chi Minh in Europe, the Soviet Union and East Asia during the 1930s are described as having revitalised opposition to colonial rule (Quang Can 2001). The message for contemporary leaders is that cultural exchange invigorates and renews domestic values.

Commentaries regarding foreign cultural borrowings are strongly influenced by perceptions about Vietnamese cultural identity. Those promoting cultural exchanges warn against an exaggerated national identity that inhibits learning from others (Nguyen Tran Bat 2002). They believe that foreign cultural values should be evaluated according to their capacity to increase social and economic competitiveness.

Counter-narratives stressing Party-led resistance to foreign domination focus instead on how 'global' culture spread by foreign trade, media, Internet communications, cinema and tourism has the potential to subvert confidence in local traditions (Tran Van Giau 1995). This discourse theme reinforces xenophobia by characterising foreign influence as 'peaceful evolution' (dien bien hoa binh) foreigners undermining Party and state authority. Its potency is demonstrated by the demotion of Le Dang Doanh, a prominent market reformer, for allegedly associating too closely with foreigners, especially Americans. ${ }^{12}$

Borrowed cultural elements are portrayed as tainting or disrupting 'core' Vietnamese values. For example, foreign ideas are blamed for alienating the young from Vietnamese culture, causing them to lose their roots (mat goc), and breeding individualism and consumerism. Party resolutions echo these concerns: 'the market economy, with its tremendous spontaneous power, has encouraged individualism and made the people attach importance to individual interests while forgetting the interests of the community'. ${ }^{13}$

Rather than evaluating cultural imports according to their capacity to benefit society, this nationalistic narrative uses politically determined criteria to guide cultural borrowing. As the nation's moral guardians, Party theorists select and promote core political and moral ideas that 'protect the "beautiful traditions" (truyen thong tot dep) and values of the country' (Le Kha Phieu 1998:42). The central concern is that 'internal factors must have the leading role in directing the relations with and deciding the choice of external factors.'

Cultural debates rarely appear in legal writings, but their influence is evident in approaches to law reform. Differences between Western laws and core Vietnamese cultural values were explored in research conducted by the Legal Research Institute (Vien Nghien Cuu Khoa Hoc Phap Ly), a body attached to the Ministry of Justice. ${ }^{14}$ Their search for legal norms in Vietnam's Imperial Codes was strongly influenced by the 'Asian values' thesis. Promoted by Asian leaders such as Singapore's Lee Kuan Yew and Malaysia's Mohamad Mahathir, this nationalisitic rhetoric maintains that Asian states can withstand 'negative' global pressures and preserve social 
stability and élite power by asserting core 'traditional', mainly Confucian, moral values. This approach was partially discredited when the East Asian economic crisis exposed deep structural flaws in the East Asian development model. Research, nevertheless, proceeded on the untested assumption that 'East Asian' cultural values will produce beneficial economic outcomes in Vietnam.

Researchers plundered Vietnam's pre-modern Imperial Codes, searching for quintessential Vietnamese-Confucian laws. In treating pre-modern legal norms as autonomous regulatory instruments, however, they detached these rules from the social, economic and cultural context that gave them meaning. Traditional preference for non-adversarial dispute resolution, for example, was attributed to a traditional Vietnamese communalism that discouraged 'individuality' and the 'self' (Dao Bao Ngoc 1999:32-5). Pre-modern political and economic constraints on court-based adjudication were ignored.

Researchers also employed a dubious methodology that read history backwards. They used prevailing cultural values to assess the contemporary utility of premodern legal norms. For example, commentators imagined the early Lê Dynasty (fifteenth century) as a golden age of political-legal innovation when indigenous commercial practices crystallised into legally enforceable rights. This construction misconstrued the stated purpose of the LêCode, which was to reproduce an imported Chinese social order (tam cuong). To the Confucian mind, close textual readings made limited sense, since legal meaning resided primarily in the moral teachings of mandarin literati (Whitmore 1995). Appeals to the letter of the law implied a disregard for morality, or worse, moral weakness. Commercial provisions in the Lê Code served a public law function to preserve village harmony and were never intended to confer private rights (Vu Van Mau 1963).

Despite voluminous writings, researchers failed to find meaningful ways to incorporate traditional norms ( $d u c$ tri) based on pre-industrial village life into a legal system regulating an educated and internationally integrated mixed-market society (Dao Tri Uc 1995). Researchers did not give legislative drafters the contextual information needed to ascertain whether pre-modern legal norms could regulate contemporary life.

Without cultural frames of reference, legal drafters must rely on vague cultural stereotypes and the perceived prestige of particular legal systems to decide whether Chinese law, for example, is intrinsically more compatible with Vietnamese culture than US or Japanese law. Cultural compatibility seemed relatively unimportant to legal borrowing during the 1960-70s, when the Party was convinced that society was evolving into a transcultural Soviet-socialist utopia. But unreflective legal borrowing is untenable in contemporary Vietnam, where the state is borrowing laws from an eclectic range of legal sources. It is also difficult to explain by reference to either inward or outward-looking cultural discourses, as both caution against wholesale legal borrowing from foreign cultures. What remains unclear is why contemporary legal borrowers have been reluctant to bring lawmaking into 
conversation with economic, moral and cultural discourses.

\section{LEGAL BORROWING DISCOURSE}

Like Soviet borrowing in the 1960s, post-doi moi legal borrowing has again superimposed foreign legal concepts over indigenous institutional and epistemological legal structures. This section examines whether contemporary lawmakers are more prepared than their predecessors to adjust borrowed law to local political, economic, moral and cultural concerns.

Three analytical threads run through the literature. First, most writers use technical legal language to analyse foreign laws. Second, some writers have reconfigured Marxist-Leninism to make legal borrowing from capitalist countries a theoretical possibility. Third, a few commentators have quietly replaced MarxistLeninism with borrowed Western sociological theory that embeds borrowed law in a broad discursive context.

Returning to the first analytical thread, most legal writers avoid sensitive political, economic and moral comparisons between imported law and domestic conditions by narrowly focusing on technical legal rules (Dao Bao Ngoc 1999; Pham Duy Nghia 2000). Consider Hoang The Lien's (1996) comparative consideration of legal capacity in the European and Vietnamese Civil Codes. His analysis examined the surface text without engaging underlying legal doctrines, much less the political, economic and moral discourses shaping legal preferences. For example, the legal capacity of companies was analysed by comparing the textual meaning of different statutory provisions, without explaining that these provisions operated in profoundly different legal systems and political economies.

There are undoubtedly many explanations for this 'black letter' law approach to legal borrowing, such as a lack of comparative law and research skills. Never far below the surface is the political concern that law should reflect the 'will of the ruling class', as interpreted by the Party. The LNA project, coordinated by the Ministry of Justice, illustrates this problem. It assessed the suitability of Vietnamese laws and legal institutions according to their capacity to realise the four socioeconomic development strategies approved by the Ninth Party Congress in 2001. Ministry officials ignored economic reports showing that the Party's economic integration policy produces inequitable outcomes and committed the government to legal reforms required to 'meet international standards in order to help Vietnam perform her international commitments' (Ministry of Justice 2002:25). Political and cultural arguments that legal imports may erode 'core' Vietnamese cultural values were also disregarded.

If legal needs are primarily assessed from Party and state political perspectives, it is comparatively unimportant whether legal imports are compatible with local conditions. Although lawmakers are generally well aware that incongruent laws are unlikely to produce desired outcomes, they feel constrained from localising law in a closed epistemological environment where legal discourse is subordinate to 
political imperatives. Borrowed laws are consequently treated like technical fragments detached from a political, economic, moral and cultural context.

The second analytical thread reveals the tension between political constraints over legal thinking, and government policies that now encourage lawmakers to consider the social impact of new law. ${ }^{15}$ This policy has emboldened some theorists to find new ways to localise borrowed law. While retaining the belief that MarxistLeninism 'is still the most scientific and creative ideology in the world', they stress the need to apply socialist theory flexibly to new conditions (Le Honh Hanh 1998:319).

Dialogue with Soviet lawyers slowed after the Russian Federation was formed, and Vietnamese theorists began looking for new sources of legal thinking. Most theorists lacked the linguistic skills to engage deeply with Chinese theory and, in any event, considered Chinese legal thinking comparatively underdeveloped. Some theorists turned to internal sources for new ideas, while others looked outside Vietnam for inspiration.

Dao Tri Uc was among those many theorists who sought new ideas from local discourse. As previously mentioned, he attempted to make borrowed Soviet theory more relevant by reconfiguring Marx's base-superstructure metaphor to justify legal borrowing from capitalist regimes. Others creatively used Ho Chi Minh's eclectic blend of Western, Marxist-Leninist and pre-modern Vietnamese thinking as a 'political umbrella' to smuggle new concepts into the legal discourse. They selectively plundered Ho Chi Minh's thoughts for 'rule of law' or Confucian aphorisms to open the epistemological environment to ideas beyond the narrow parameters permitted by class-analysis (Tran Dinh Huynh 1999; Le Minh Tong 2000).

Borrowing from external discourses, some theorists have attempted to expand the epistemological repertoire by increasing the narrow range of legal relationships recognised by orthodox Soviet legal taxonomies (Nha Nuoc va Phap Luat 1996). Soviet jurisprudence received into Vietnam during the 1960s used law instrumentally to 'adjust social relationships' (dien chinh). The state first classified 'social relationships' (quan he xa loi) according to shared class characteristics and then enacted laws to regulate social relationships within predetermined 'independent law branches' (nganh luat doc lap). Soviet legal taxonomies functioned well enough in a command economy, but now constrain Vietnamese lawmakers from thinking about market laws in conceptually coherent ways.

Soviet finance law taxonomies illustrate the problem. They were developed to classify financial transactions in a centrally planned economy and influence the way legal actors conceived law. For example, Soviet taxonomies classify tendering rules as public finance law, because money is paid from the state budget. Consequently, it is difficult for lawyers to see the private law underlying tendering rules.

The imported notion that 'fair and equitable' laws (cong bang cua phap luat) must balance social interests directly challenges the instrumental Soviet notion that law adjusts social relationships. As one writer put it, 'law should be attached to politics but is not a servant of the state' (Nha Nuoc va Phap Luat 1996:116-7). In other words, laws implement political policy, but are not 'management tools' (cong cu 
quan $l y$ ). This new thinking allows lawyers to move beyond top-down Soviet taxonomies and conceptualise horizontal legal relationships.

Other theories have attempted to blend Marxist thinking with Western thoeries that stress linkages between law and culture, especially legal culture (van hoa phap $l y$ ). Their writings unconsciously borrow from Durkheim's 'collective consciousness' - the notion that if society is an invisible moral environment surrounding individuals, then law is the visible manifestation of 'community sentiment' (Durkheim 1960). Though arguing that law reflects social mores and 'community sentiment' (tinh lang nhia xom), they are unwilling to repudiate the Marxist base-superstructure metaphor and embrace a fully realised alternative social theory that explains the interdependence between law and society (Le Minh Tam 1998). Without taking this final step, their theorising lacks the methodological tools lawmakers need to codify ideas from local discursive narratives.

The third analytical thread contrasts with the previous theoretical approaches, because it uses Western sociological theory to bypass Marxist-Leninism. This subtle shift in thinking is revealed as much by what is not said as by explicit arguments. These writers rarely mention Marxist-Leninist formulas and clearly separate political, economic, moral and legal arguments. Unfettered by the basesuperstructure metaphor, they are free to conceptualise complex interactions between borrowed law and society.

Some German-trained academic lawyers argue from Weberian theory that imported foreign commercial laws (du nhap luat kinh te nuoc ngoai) will only induce desired behaviour where they are popular with the people (tinh pho thong), welldefined (xac dinh on dinh), predictable (co the du doan truoc) and transparent (tinh ro rang) (Pham Duy Nghia 2000, 2001). They maintain that hastily borrowed Western legal rules laws are incompatible with domestic 'legal ideology' (tu duy phap ly) and will not transplant successfully.

Pham Duy Nghia (2000) argued that many Western commercial legal norms introduced capitalist political and economic ideals that were incompatible with the small-scale family structures and sentimental bonds that characterise Vietnam's 'peasant legal culture' (nen phap ly nong dan). He illustrated this point with Articles 8 and 9 of the Commercial Law 1997, which imported Western unfair competition and consumer protection principles that functioned like idealistic political slogans (khau hieu) in Vietnam's highly state-directed economy. He concluded that borrowed Western law is generally incompatible with domestic economic and cultural conditions, but legal importation is the only practical means of quickly enacting the commercial legal framework required for international economic integration. 'Legal harmonisation' (hai hoa phap luat) is a long-term project requiring the state to devote more resources to researching and reconciling imported precepts with local social conditions.

\section{CONCLUSION}

The introduction of the law-based state doctrine in 1991 opened up legal debate by 
allowing Vietnamese commentators to re-evaluate long-standing socialist legal concepts. Their richly variegated legal discourses, considered in this chapter, convey multiple understandings of socialist law. In some areas socialist law has assimilated capitalist legal rights; in other areas it resembles decades-old Soviet discourse.

It is also possible to infer from the legal discourse three interrelated propositions that suggest the potential for legal change. First, law is a process used by competing social agents to order state power. Second, power struggles determine whether epistemological settings governing legal discourse are closed and self-referential, or open and willing to engage new ideas. Third, rules that control the levers of power are more strongly contested than legal ideas on the periphery of power relations (Dezalay and Garth 2002).

Democratic centralism and collective mastery rapidly became the central organisational principles governing power relationships among Vietnamese Party and government structures. These principles remain deeply embedded in political and moral narratives and resist conceptual changes that may disrupt longstanding power sharing arrangements.

In contrast, socialist legality was for decades enmeshed in a quasi-Soviet legal language understood by only a few élite Soviet-trained lawyers. As a peripheral discourse with little direct bearing on political power, socialist legality was less constrained by political discourse than democratic centralism and collective mastery. Especially in the commercial arena, where the Party actively encouraged legal change, socialist legality has rapidly evolved in response to new economic ideas. Imported commercial laws are now beginning to supply the normative rules that were once almost exclusively the prerogative of Party edicts and moral campaigns. Change is much slower where legal thinking impinges on Party and state power. For example, commentators discussing the capacity for socialist law to constrain Party political power are not permitted to consider Western 'rule of law'.

Power-sharing arrangements have also influenced the epistemological conventions that allow socialist ideas to change. Responding to market forces, rigid base-superstructure determinism has partially given way to a Durkheimian and Weberian conceptual framework that places law in a broad social, political and economic matrix. Legal discourse is learning from new economic ideas, especially concepts sponsored by international trade agreements. Other epistemological barriers are also dissolving. Marxist antipathy towards East Asian culture has been replaced by a 'reality' manufactured to support contemporary development objectives. Utopian yearnings for a model socialist society have been discarded in favour of East Asian developmentalism with 'socialist' characteristics. In the arenas where legal discourse has emerged from the shadow of political discourse, socialist law has become noticeably more legalistic and rule-oriented.

The Party and state have not been able to quarantine sacrosanct socialist principles entirely from change. Those advocating market regulation and a facilitative legal system openly challenge 'state economic management', which is a central component of Party 'leadership'. Marxist-Leninist 'scientific' infallibility, 
another concept closely allied to Party 'leadership', is also being eroded by sociological arguments that law belongs in a social context and is not merely an instrument of Party power. For the present, however, Party 'leadership' over politically sensitive national security issues remains beyond the reach of legal accountability.

This analysis locates the meaning of socialist law in 'officially' sanctioned discursive narratives. As legal thinking increasingly interacts with local 'unofficial' discourses, core Marxist-Leninist principles are giving way to new regulatory approaches. This trend is especially evident in the commercial arena, where imported laws interact and form hybrids with local norms and practices. In other social arenas, where political and moral discourses remain more powerful than legal discourse and without compelling reasons to legalise or constitutionalise political processes, 'socialist law' is likely to remain faithful to longstanding Marxist-Leninist concepts.

\section{NOTES}

1 As editor of the Supreme Court journal Tap San Tu Phap, Dinh Gia Trinh was a prolific and influential writer (Dinh Gia Trinh 1961).

2 Writing in the Vietnamese Court Review (Tap San Tu Phap), several Soviet law professors set out the basic principles of Soviet law (Lets Noi 1961).

3 Vietnamese writers cited V. I. Lenin in Nha nuoc va Cach Mang [State and Revolution], Chapters Two and Three. Lenin proposed that the working class should centralise power in their hands and power should be distributed on the basis of democracy. This ideology gave political and social meaning to democratic centralism (Dinh Gia Trinh 1964a).

4 Interviews with Le Kim Que, President, Bar Association of Hanoi, Hanoi, 1 October 1999, and Nguyen Thuc Bao, Former Legal Adviser to the Ministry of Agriculture, Hanoi, 11 September 2000.

5 Interviews with Pham Huu Chi, former adviser to the Minister of Justice, Vice Rector of the Hanoi Law College and member of the Company Law Drafting Committee, 1992-94.

6 Current legal thinking has been gleaned from political, economic, moral, cultural and legal discourse in Party and state publications, and also from interviews with state officials and academics.

7 Interviews with Nguyen Dinh Cuong, Director of the Enterprise Department, CIEM, July 2002; March 2003.

8 Most of the report was written in 2002 by John Bentley and Theodore Parnell, UNDP legal advisers to the Ministry of Justice.

9 Interviews with JICA long-term legal representatives Legal Coordinator Kawazu Shinsuke and Judicial Expert Takeuchi Tsutomu, Hanoi, January 2002. See generally Lawrence Tshuma (1999:75-96).

10 Resolution No. 48/2001/QH10 on the Ratification of the Agreement between the Socialist Republic of Vietnam and the United States of America on Trade Relations, Annex F.

${ }^{11}$ Cultural discourse, understood as arguments concerning the framework that gives meaning and sense to people's lives, comprises many interwoven discourse modes, such as moral, political and legal communication. It is treated as a separate discursive category, partly because it is difficult to unravel the discrete discursive modes and partly because for centuries the Vietnamese have evaluated their interaction with foreigners through a cultural framework.

12 Interview with Le Dang Doanh, Hanoi, January 2001.

13 Resolution of the Fifth Plenum of the Central Party Committee, 2001.

14 The project was initiated by the Minister of Justice, Nguyen Dinh Loc, to overcome some of the problems experienced by drafting committees in reconciling borrowed law with Vietnamese conditions. Interview with Duong Thi Thanh Mai, Deputy Director of the Institute of Law 
Research, Ministry of Justice, Hanoi, March 1999.

15 Law on the Promulgation of Law Instruments (amended 2003).

\section{REFERENCES}

Avineri, S., 1969. 'Introduction', in S. Avineri (ed), Karl Marx on Colonialism and Modernization, Doubleday, New York:6-16.

Beck, A., 1994. 'Is law an autopoietic system', Oxford Journal of Legal Studies, 14(3):401-18.

Communist Party of Vietnam, 2001. 'Political report of the Party Central Committee, 8th tenure, to the 9th National Congress', reproduced in Communist Party of Vietnam, 9th National Conference Documents, The Gioi Publishers, Hanoi:75-82.

Cong Tac Ke Hoach, 1976. 'Carrying out good national economic planning and summarizing national economic planning well', A pril, 9, 9-11; JPRS 67923. 16-22.

Dao Bao Ngoc, 1999. 'Regional integration in Asia: from the perspective of the interaction between legal culture and legal regimes', Nha Nuoc va Phap Luat [State and Law], 7:30.

Dao Minh Quang, 1993. 'History of land tenure in pre-1954 Vietnam', Journal of Contempary Asia, 23(1):84-92.

Dao Tri Uc, 1995. 'Introduction to the study of Vietnam's state history and law', Vietnam Law and Legal Forum, 1(8):38-40.

- 1999. 'The principle of legality ('Phap che') and its presentation in the criminal code of Vietnam', Tap Chi Cong San [Communist Review], January:18-22.

—_ and Le Minh Thong, 1999. 'Su Tiep Nhan Cac Gia Tri Phap Ly Phuong Dong va Phuong Tay Doi Voi Su Phat Trien Cac Tu Tuong Phap Ly Viet Nam' [Reception of oriental and occidental legal values in the development of Vietnamese legal ideology]', Nha Nuoc va Phap Luat [State and Law], 5:3-16.

Dezalay, Y. and Garth, B.G., 2002. The Internationalization of Palace Wars, University of Chicago Press, Chicago.

Dinh Gia Trinh, 1961. 'May Y Kien Dong Gop Ve Van De Bao Ve Phap Che [Some opinion on the protection of legality]', Tap San Tu Phap, 3:20-32.

__, 1964a. Nghien Cuu Nha Nuoc va Phap Quyen [Studies about State and Legality], Nha Xuat Ban Su Hoc, Hanoi.

—, 1964b. 'Phap Che [Legality]', Tap San Tu Phap, 4:28-29.

__ 1965. 'May y kien ve tinh dan toc va tinh khoa hoc cua thuat ngu luat hocNhan xet phe phan ve mot so thuat ngu thong dung [Nationalistic and scientific use of legal terminology: criticisms of common legal terms]', Tap San Tu Phap, 3:24-26.

Do Moi, 1992. Sua Doi Hien Phap Xay Dung Nah Nuoc Phap Quyen Viet Nam, Day Minh Su Nghiep Doi Moi [Amending the Constitution, Establishing a Law-based State and Promoting Doi Moi Achievements]', Nha Xuat Ban Su That (Truth Publishing House), Hanoi. 
Do Muoi, 1992. 'Sua Doi Hien Phap, Xay Dung Nha Nuoc Phap Quyen Viet Nam, Day Manh Su Nghiep Doi Moi [Revising the constitution, building a lawgoverned state and promoting renovation]', Tap Chi Cong San, 5:6.

Doan Trong Truyen, 1997. 'Market economy and state management', Vietnam Social Sciences, 4:10-16.

Durkheim, E., 1960. Sociology and its Scientific Field, Free Press, New York [tr. G. Simpson].

Fforde, A., 1999. 'From plan to market', in A. Chan, Kerkvliet, B. and Unger, J. (eds), Transforming Asian Socialism: China and Vietnam compared, Allen and Unwin, Sydney:44-63.

Giang Chau, 2003. 'Trade to firm up after solid promotion during first year', Vietnam Investment Review, 10 February:1.

Ginsburgs, G., 1973. 'Soviet sources on the law of North Vietnam', Asian Survey, 13(7):659-76.

Grossman, J.B., 1971. 'Introduction', in J.B. Grossman and M.H. Grossman (eds), Law and Change in Modern America, Goodyear Publishing Co, Pacific Palisades, California:1-10.

Ho Chi Minh, 1994. 'Political report at the second national congress of the Vietnam Workers Party', in Selected Writings of Ho Chi Minh, Gioi Publishers, Hanoi:10129.

_ 1995a. Complete Works, Volume 5, The National Political Publishing House, Hanoi.

—, 1995b. Complete Works, Volume 8, The National Political Publishing House, Hanoi.

Hoang Phuoc Hiep, 2001. ‘Hiep Dinh Thuong Mai Viet Nam—Hoa Ky va Van De Nghien cuu Lap Phap o Viet Nam [The Vietnam-US bilateral trade agreement and legislative issues in Vietnam]', Tap Chi Nghien Cuu Lap Phap [Legislative Studies Review], 2:60-78.

Hoang Quoc Viet, 1962. 'Viec Xay Dung Phap Che Xa Hoi Chu Nghia va Giao Duc Moi Nguoi Ton Trong Phap Luat [Building up socialist legality and educating people to respect laws]', Hoc Tap [Study Review], 6:14-18.

- 1964. 'Can Dam Bao Cho Phap Luat Duoc Ton Trong Trong Cong Tac Quan Ly Linh Te Cua Nha Nuoc [We must ensure the enforcement of law in state economic management]' in Nghien cuu Nha Nuoc va phap quyen [Studies about State and Law], Truth Publishing, Hanoi:31-41.

__ 1973. Tang Cuong Che Xa Hoi Chu Nghia Trong Cong Tac Quan Ly Xi Nghiep [Strengthening Socialist Legality in Management Enterprises], Nhan Xuat Ban Su That, Hanoi.

Hoang The Lien, 1996. 'Subject system in Vietnam's civil code', Vietnam Law and Legal Forum, 2(18):22-25.

Hoc Vien Hanh Chinh Quoc Gia (The National Administrative School), 1991. Ve Cai Cach Bo May Nha Nuoc [On the Reform of the State Apparatus], Truth Publishing House, Hanoi. 
Lavigne, P., 1985. 'Democratic centralism', in F.J.M. Feldbrugge, G.P. Vanden Berg and W.B. Simons (eds), Encyclopedia of Soviet Law, Second edition, Martinus Nijhoff Publishers, Dordrecht:31-53.

Le Duan, 1979. Nhan Dan Lao Dong Lam Chu Tap The la Sui Manh, la Luu Duy Cua Chung Chanh Vo Sau [The Labouring People Hold Collective Mastery which is the Force Driving Proletarian Dictatorship], Unpublished speech given by Le Duan, Hanoi, 2 April.

—, 1994. Le Duan: selected writings, The Gioi Publishers, Hanoi.

Le Honh Hanh, 1998. Giao Trinh Ly Luan Nha Nuoc va Phap Luat [Themes of State and Law], Nha Xuat Ban Cong An Nhan Dan, Hanoi.

Le Kha Phieu, 1998. 'Party leader addresses cultural officials', Nhan Dan, 9 October:1, 5 [tr. FIBIS East Asia Daily Reports 98-289].

Le Minh Quan, 1997. 'On the necessity to build a social law-governed state in Vietnam', Vietnam Social Sciences, 5:27-33.

Le Minh Tam, 1998. Giao Trinh Ly Luan Nha Nuoc va Phap Luat [Themes of State and Law], Nha Xuat Ban Cong An Nhan Dan, Hanoi.

Le Minh Tong, 2000. Mot So De Ve Nha Nuoc Pha Quyen Trong Boi Canh Viet Nam [Some Issues about the Law Based State in the Context of Vietnam], Unpublished paper presented to conference on Rule of Law and its Acceptance in Vietnam, Institute of State and Law, 11 September, Hanoi:1-2.

Le Phuong, 1994. Civil Society: From Annulment to Restoration, Unpublished paper presented at the Vietnam Update Conference Doi Moi,The State and Civil Society, Canberra, 5 November.

Le Thanh Nghi, 1975. Mot So Van De Co Ban Trong Quan Ly Kinh Te Xa Hoi Chu Nhgia [Several Basic Matters of Socialist Economic Management], Nhan Xuat Su That, Hanoi.

Le Thi, 1977. 'Create a correct relationship between the collective and the individual in the socialist system', Tap Chi Cong San, 8:54-58.

Le Van Luong, 1960. 'Tang Cuong Che Do Tap Trung Dan Chu Trong Dang Ta' [Strengthening the democratic centralism in our party], Hoc Tap, 6:27-31.

Lets Noi, B.M., 1961. ‘Phap Che Xa Hoi Chu Nghia Xo Viet: Tinh Lich Su va Tinh Giai Cap Cua Phap Che [Socialist legality historical and class features], Tap San Tu Phap, 6:36-41.

Letsoni, V., 1963. 'Nen Tu Phap Cua Nuoc Viet Nam Dan Chu Cong Hoa [The judiciary of the Democratic Republic of Vietnam]', Tap San Tu Phap, 11:26-28.

Luhmann, N., 1987. A Sociological Theory of Law, Routledge, London [tr. by E. King and M. Albrow].

Luu Ha Vi, 1997. 'Vietnam: industrialization viewed from the interplay between productive forces and relations of production', Economic Development Review , 1 January:20.

Mai Huu Thuc, 2001. 'Characteristics of market economy with socialist orientation in Viet Nam', Vietnam Social Sciences, 1:20-25. 
Marx, K., 1969 [1877]. 'Otechestvenniye Zapiski', reproduced in S. Avineri (ed.), Karl Marx on Colonialism and Modernization, Doubleday, New York:6.

Minh Khuong, 1999. 'Efficiency and competitiveness of the Vietnamese economy', Vietnam's Socio-Economic Development, 19:3-13.

Ministry of Justice, 2002. Report on the Comprehensive Needs of Developing Law Making Bodies, Law Implementation and Enforcement, International Treaty Reception and Dispute Resolution, Ministry of Justice, Hanoi.

Ngo Cuong, 1997. 'Vietnam fatherland front presidium conference contributes ideas to third plenum draft', Dai Doan Ket, 29 May:1, 2 [tr. FBIS East Asia Reports 97-119].

Ngo Van Thau, 1982. Tim Hieu ve Nha Nuoc [Studies about State and Law], Nha Xuat Ban Phap Ly, Hanoi.

Nguyen Khac Vien, 1974. Tradition and Revolution in Vietnam, Indochina Resource Center, Berkeley.

Nguyen Khanh Toan, 1964. 'Nha nuoc va phap quyen xa hoi chu nghia va cong tac nghien cuu luat hoc [State and Law: socialist state and legal research]', in Nghien сии Nha Nuoc va phap quyen [Studies about State and Law], Truth Publishing, Hanoi:7-19.

Nguyen Minh Tu, 1999. 'Integration of Vietnam's economy into the regional and world economy at present', Vietnam Social Sciences, 6:91-96.

Nguyen Nhu Phat, 1997. 'The role of law in Vietnam during the formation of the market-driven mechanism in Vietnam', in J. Gillespie (ed.), Commercial Legal Development in Vietnam: Vietnamese and foreign commentaries, Butterworths Asia, Singapore:398-413.

Nguyen Nien, 1976. 'Several legal problems in the leadership and management of industry under the conditions of the present improvement of economic management in our country', Luat Hoc [Juridical Science], 14:33 [tr. J.P.R.S., 30 September 1976:34-36].

Nguyen Phu Trong, 1999. 'Effect a new change in the study of political theory of cadres and Party members', Tap Chi Cong San (Communist Party Review), 7 November:6-9.

Nguyen Tan Dung, 2002. 'Building a socialist-oriented independent and sovereign economy', Quan Doi Nhan Dan [People's Army], 13 September:3.

Nguyen Thanh Tam, 2001. 'Phap Luat So Huu Tri Tue Cua Viet Nam Trong Hoi Nhap Quoc Te [Vietnamese intellectual property laws in international integration era]', Tap Chi Nghien Cuu Lap Phap [Legislative Studies Review], 2:46-54.

Nguyen The Phung, 1960. Nguyen Tac Tap Trung Dan Chu: Dam Bao Thuc Hien Tot Nhiem Vu Cach Mang Truoc Mat [The Principle of Democratic Centralism: a justification for implementing the revolutionary task before us], Nha Xuat Ban Su That, Hanoi.

Nguyen Thi Oanh, 1998. 'Tu Phim Nghiep Chuong Thu Ban Ve Van Hoa' [Let's discuss culture from the film 'Causes and Consequences'], Tuoi Tre [Youth], 18 October:3-8. 
Nguyen Tran Bat, 2002. 'Culture in recognition of its value', Essays, collection of unpublished papers, Hanoi, 1.

Nguyen Van Tai, 1996. 'On the state ruled by law and a multipartisan regime', Vietnam Social Sciences, 1:3-8.

Nha Nuoc va Phap Luat [Institution of State and Law], 1996. Nhung Van De Ly Luan Co Ban Ve Nha Nuoc va Phap Luat [Basic Theoretical Issues about State and Law], Nha Xuat Ban Chinh Tri Quoc Gia, Hanoi.

Nicholson, P., 2001. Borrowing Court Systems: the experience of the Democratic Republic of Vietnam, 1945-1976, PhD Thesis, University of Melbourne, Melbourne.

Pham Duy Nghia, 2000. 'Phap Luat Thuong Mai Viet Nam Truoc Thach Thuc Cua Qua Trinh Hoi Nhap Linh Te Quac Te [Commercial law faces the challenges of international economic integration]', Nha nuoc va phap luat, 6:9-18.

__ 2001. 'Mot So Anh Huong Truc Tiep Cua Qua Trinh Hoi Nhap Kinh Te Khu Vuc va The Gioi Doi Voi Phap Luat Viet Nam [Some direct influences of the world's and regional economic integration into Vietnamese law]', Tap Chi Nghien сии Lap Phap [Legislative Studies], 2:3-8.

— 2002. 'Tiep Nhan Phap Luat Nuoc Ngoai-Thoi Co va Thach Thuc Moi Cho Nghien Cu Lap Phap [Transplantation of foreign law: chances and challenges for legislative studies in Vietnam]', Tap Chi Nghien cuu Lap Phap [Legislative Studies], 5:50-57.

Pham Van Bach, 1970. ‘Le Nin Voi Van De Phap Che Xa Hoi Chu Nghia [Lenin and socialist legality]', Tap San Tu Phap, 3:9-16.

Pham Van Chuc, 2002. 'Dang Co Chang Mot Toan Cau Hoa Cho Moi Nguoi [Is there now a globalisation for all people?]', Tap Chi Cong San, 12:33-37.

Pham Van Dong, 1952. May Van De Cot Yeu cua Chinh Quyen Dan Chu Nhan Dan Viet Nam [Some Crucial Aspects of the People's Democratic Regime in Viet Nam], Ban Chap Hanh Trung Uong, Hanoi.

, 1977. 'Strengthen the Party leadership, carry out the state's managerial functions and develop the people's right to ownership in order to successfully fulfil the 1977 state plan', Ho Chi Minh City Domestic Service, 22 January:4. Reproduced in FIBIS East Asia Daily Service 16, 25 January:K9, K11-K13.

Potter, J. and Wetherell, M., 1987. Discourse and Social Psychology, Blackwell, London.

Quang Can, 2001. 'Some reflections on Marxist philosophy in the perspective of Eastern culture', Vietnam Social Sciences, 1:8-11.

Sarogoratisk, 1961. 'Vai Tro va Quan He Giua Cuong Che va Thuyet Phuc Cua Phap Luat Trong Thoi Ly Xay Dung Chu Nghia Cong San Tren Quy Mo Rong Lon [Roles and relations between enforcement and legal education in the communist period]', Tap San Tu Phap, 11:41-57.

See Huu Tho, 1998. 'Some problems concerning ideological work in the new situation', Tap Chi Quoc Phong Toan Dan [People's Army Review], 9(September):10-15. 
Shih, C-Y., 1996. 'China's socialist law under reform: the class nature reconsidered', The American Journal of Comparative Law, 44(4):627-646.

Song Thanh, 1995. 'President Ho Chi Minh laid the foundation for a law-governed state in Vietnam', Vietnam Law and Legal Forum, 1(9):3-6.

Ta Thu Khue, 1963. 'Can Than Trong Trong Viec AP Dung Kinh Nghiem Lien-xo Voa Trinh Tu Phuc Tham [We need to be cautious in applying soviet experience in appellate procures], Tap San Tu Phap, 2:12-14.

Ta Van Tai, 1982. 'Vietnam's code of the Lê dynasty (1428-1788)', American Journal of Comparative Law, 30(3):523-53.

Teubner, G., 1993. Law as an Autopoietic System, Blackwell, Oxford.

Thanh Duy, 1997. ‘Co So Khoa Hoc va Van Hoa Trong Tu Tuong Ho Chi Minh Ve Nha Nuoc va Phap Luat [Scientific and cultural basis of Ho Chi Minh's ideas of state and law], Tap Chi Cong San, January:26-28.

Tran Dinh Huynh, 1999. 'Moi Quan He Giua Tri Luc-Dao Duc-Phap Luat Trong Quan Ly Dat Nuoc Cua Chu Tich Ho Chi Minh [Relationship between intelligence-morality-law in Ho Chi Minh's thought on administration], To Chuc Nha Nuoc, 5:3-5.

Tran Hieu, 1971. 25 Nam Xay Dung Nen Phap Che Viet Nam [25 Years of Building Vietnamese Legality], Nha Xuat Ban Lao Dong, Hanoi.

Tran Thu Hang, 1999. 'Vietnam's trade in the course of international integration', Vietnamese Studies, 2:113-23.

Tran Van Giau, 1995. 'Methodologies for incorporating cultural factors into development projects and planning', in Pham Xuan Nam (ed.), Methodologies for Incorporating Cultural Factors into Development Projects and Planning, Social Sciences Publishing House, Hanoi:169-75.

Tran Van Nam, 2002. 'On the ordinance on the most favoured nation and the national treatment in international trade', Vietnam Law and Legal Forum, 8(96):25-26.

Tran Viet Phuong, 1999. 'Globalisation and integration into the world economy', Vietnam Social Sciences, 6:79-84.

Tran Xuan Truong, 2002. 'Our Party is morality, civilisation', Tap Chi Cong San [Party Review], 3 February. Available online at www.tapchicongsan.org.vn.

Truong Chinh, 1948. Marxism and Vietnamese culture, Report delivered to the Second National Cultural Conference, July 1948, reproduced in Truong Chinh Selected Writings.

— 1968. 'Forward along the path charted by Ho Chi Minh', reproduced in Truong Chinh, 1994. Selected Works, The Gioi Publishers, Hanoi, 547.

Tshuma, L., 1999. 'The political economy of the World Bank's legal framework for economic development', Social and Legal Studies, 8(2):75-96.

Vo Khanh Vinh, 1997. 'Mot So Van De Ve Xa Hoi Hoc Xay Dung Phap Luat [A number of issues in sociological lawmaking]', Nha Nuoc va Phap Luat [State and Law], 8:14-20. 
Vu Anh Tuan, 1998. 'Voi Mat Trai Cua Kinh Te Thi Truong [Laws and negative aspects of the market economy]', Nghien Cuu Ly Luan [Journal of Theoretical Studies], 3:26-31.

Vu Khieu, 1999. 'President Ho Chi Minh and culture', Nhan Dan on-line, www.nhandan.org.vn/english/people/19990517.html.

Vu Ngoc Nhung, 1999. 'Role of state in market economy with socialist orientation', Vietnam Social Sciences, 6(74):19-24.

Vu Tuan Anh (ed.), 1994. The Role of the State in Economic Development: experiences of the Asian countries, Social Sciences Publishing House, Hanoi.

Vu Van Mau, 1963. 'Le Driot Prive Vietnamien Moderne Compare Avec Les Droits Occidentaux', in Quelques Aspects Technique de la Reception des Driots Occidentuax, Association Nationale de Droit Compara, Saigon:3-22.

Vyshinski, A., 1982 [1936]. 'Raise the red banner of socialist legality', Sots. Zak., November, cited in G.B. Smith, 'Development of "socialist legality" in the Soviet Union', in F.J.M. Feldbrugge and W.B. Smith (eds), Perspectives on Soviet Law for the 1980s, Martinus Nijhoff Publishers, The Hague, 81-82.

Whitmore, J., 1995. 'Chung-hsing and Cheng-t'-ung in texts of and on sixteenthcentury Viet Nam', in K.W. Taylor and J.K. Whitmore (eds), Essays Into Vietnamese Pasts, Studies on Southeast Asia 19, Cornell University Press, Ithaca:116-32. 